\title{
An Empirical Study on Economic Growth and Carbon Emissions in China
}

\author{
Huayong Niu ${ }^{1}$ \\ ${ }^{1}$ International Business School, Beijing Foreign Studies \\ University, China
}

\begin{abstract}
The aim of the paper is to explore the empirical relationship between economic growth and carbon dioxide emissions in China, and investigate what are the main determinants of carbon emissions and how are they affect it. We analyzes panel data of the 30 provinces with a time period from 2000 to 2008. The research finds no compelling evidence for the existence of Environmental Kuznets Curve. Further research is needed.
\end{abstract}

Keywords: Economic growth; Carbon emissions; Environmental Kuznets Curve; Pollution Haven

\section{Introduction}

The threat of climate change has attracted great attention in recent years. One of the most important issues is how to reduce carbon emissions, since $\mathrm{CO}_{2}$ is considered to be the main driving force behind global warming. As the world's biggest carbon dioxide emitter, China has embarked on great efforts to cut greenhouse gases. However, $\mathrm{CO}_{2}$ emissions are still increasing. One reason might be carbon dioxide emissions cause problems on a regional scale, therefore the incentive for free-riding is high ( $\mathrm{He}$ and Richard, 2010). Another possible rationale is the assumption that while pollution increase with economic growth, there comes a point after which pollution goes down (Environmental Kuznets Curve hypothesis). Then specialized environmental regulation is not necessary, environmental deterioration will diminish automatically. Therefore a careful analysis of economic growth and carbon emissions is necessary. This objective of this paper is to examine the empirical relationship between carbon emissions and economic growth within China, and investigate what are the main determinants of carbon emissions.

\section{Analysis of the theoretical links and empirical evidence}

\subsection{Economic growth and $\mathrm{CO} 2$ emissions}

Existing research on the relationship between environmental quality and economic growth mainly focuses on Environmental Kuznets Curve (EKC) approach. According to the EKC hypothesis, the relationship between

\author{
Han $\mathrm{Li}^{1}$ \\ ${ }^{1}$ International Business School, Beijing Foreign Studies \\ University, China
}

per capita GDP and per capita pollutant emissions has an inverted-U shape. This implies that, past a certain point, economic growth may actually be beneficial to environmental quality.

Theoretical and empirical studies in general agree on the existence of the inverted- $U$ form relationship between income level and some local pollution indicators such as wastewater discharge and suspended particles. However, the question of the existence of the EKC for the global pollution case of carbon dioxide has not yet been fully resolved (He and Richard, 2010). From a theoretical point of view, the original inverted- $U$ relationship is less likely for $\mathrm{CO}_{2}$ emissions since these emissions cause problems on a much lager scale, and the social costs of global warming accrue both across time and space. Therefore the incentive for free-riding is much stronger and the positive correlation between income and $\mathrm{CO}_{2}$ emissions tends to persist even for very high income levels (Arrow et al., 1995).

\subsection{Decomposition of the economic growth and the environment relationship}

A number of previous studies have examined the relationship between economic growth and environmental quality, as mentioned earlier. However economic growth is a compounded variable, like a "black box", the separate effects of a variety of underlying influences are still ambiguous. Panayotou (1997) revealed that without explicit consideration of the underlying determinants of environmental quality, the scope of policy intervention is unduly circumscribed. In order to identify the different effects of economic development on environment and distinguish which is the main determinant of the relationship, we decompose the economic growth and environment relationship into three effects, scale effect, composition effect and income effect. Previous identified by Panayotou (1997) and Islam, Vincent and, Panayotou (1999).

\subsubsection{Scale effect}

As economic develops economic activities expand, the larger the scale of economic activity the higher the level of pollution, if the nature of that activity remains the same. Growing economic activity requires larger inputs of energy and material, and generates larger quantities of waste byproducts. One reason is that economic growth increases energy demand and the growth of economic output will 
also raise the output of carbon emissions. Another reason is the increasing transportation accelerates the deterioration of air quality.Therefore carbon emissions increase monotonously with the increasing of economic scale.

\subsubsection{Composition effect}

The structure changes along with economic growth have significant influence on environmental quality, since different composition of economic activities relates to different pollution intensity. The composition effect reduces pollution if the economy specialises in sectors with lower energy intensities than average, and vice versa, the sign depends on the specialization patterns of economies. In early stages of development, the economic sectors shift from agriculture-based to industry. The transition results in increasing pollution as mass production and consumption grow. Then in the further development process, activity | moves typically from industry to the

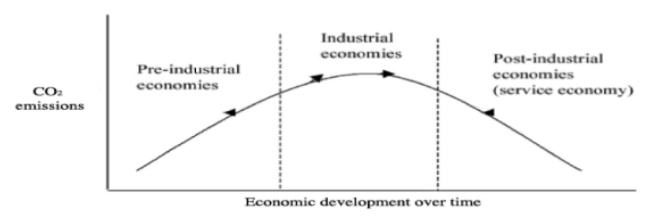

Figure 1. Composition effect for $\mathrm{CO}_{2}$ emissions

service-based economy, or from heavy industry to lighter industry. The transition results in decreasing degradation due to the lower environmental impact of service sector (Galeotti and Lanza, 2005; Stern, 2004).

As the Figure 1 illustrates, the composition effect is likely to be an inverted-U relationship of GDP over time. The changing share of industry in GDP may represent the structural change, as the industry share rises and falls, carbon emissions rise and fall as well.

\subsubsection{Income effect}

As we have mentioned above, the turning point of EKC is that an economy reaches an income level at which residents demand a cleaner environment (demand) and can afford more efficient infrastructure (supply). Therefore the income level affects environment quality, from both demand and supply sides.

In the supply side, in the early stage of economic development, individuals are unwilling to trade consumption for investment in environmental protection, so the environmental quality declines. Once individuals reach a level of consumption, they begin to demand increasing investments in an improved environment (Galeotti and Lanza, 2005). Also in the demand side, as the income levels rise the public may demand a cleaner environment as an expression of their increased wealth (Grossman and Krueger, 1993; Hübler and Keller, 2010). Thus, more stringent pollution standards and stricter enforcement of existing laws may be a natural political response to economic growth. Antweiler et al. (2001) concluded that the income effect appear to be economically and statistically significant.

\section{Model, Data and Methods}

\subsection{Model}

This study examines the relationship between GDP and $\mathrm{CO}_{2}$ emissions. We start with the basic empirical specification, and include some control variables in order to account for the different stages of economic development, regional disparity and other structural differences. Since the independent variables do not have an immediate influence on carbon emissions. The level of emissions depend on the existing technologies and the existing structure of industrial output, which can only slowly change, therefore we employ a one-year lag for all independent variables (same as Iwta et al, 2012). The lagged independent variables also help to control for the possible endogeneity of these variables if their current value was employed.

Then the final functional form is below:

The subscripts $\mathrm{i}$ and $\mathrm{t}$ denote countries and years respectively, the variables $\mathrm{CO} 2_{i t}$ and $\mathrm{GDP}_{\text {it }}$ denote carbon emission and economic growth, IMP $\mathrm{It}_{\text {it }}$ and $\mathrm{EXP}_{\mathrm{it}}$ denote imports and exports separately, $\mathrm{IND}_{\mathrm{it}}$ denotes percentage of industrial sector added value, FDI $_{i t}$ denotes net inflows of foreign direct investment. The error terms stands for timeinvariant regional effects, denotes the location-invariant time effects, and denotes other deviation of the observed value from the true value (which is assumed to be randomly distributed with a mean of 0 and a constant variance).

\subsection{Data Descriptions}

Our sample comprises of 30 provinces with a 9 years time length from 2000 to 2008. The carbon emission data set we used is calculated by Huang Lunyun, Zhao Ding and Li Wenjing. Since China has not publicly announced any data about carbon emissions, they used the data of fossil energy resources consumption to calculate $\mathrm{CO}_{2}$ emissions, with the methods developed by the Intergovernmental Panel on Climate Change (IPCC) (2006) as well as National Coordination Committee for Climate and the Energy Research Institute of National Development and Reform Commission (2007).A full definition of the variables is given in Table 1 below. 
Table 1. Data information

\begin{tabular}{|l|l|l|l|}
\hline $\begin{array}{c}\text { Variabl } \\
\text { es }\end{array}$ & Definition & $\begin{array}{l}\text { Dimens } \\
\text { ion }\end{array}$ & \multicolumn{1}{|c|}{ Source } \\
\hline $\mathrm{CO}_{2}$ & $\begin{array}{l}\mathrm{CO}_{2} \\
\text { emissions } \\
\text { per capita }\end{array}$ & $\begin{array}{l}\text { tonnes } \\
\mathrm{CO}_{2} / \\
\text { capita }\end{array}$ & $\begin{array}{l}\text { Calculated by } \\
\text { Zhao Lunyun et } \\
\text { al. (2012) }\end{array}$ \\
\hline gdp & $\begin{array}{l}\text { GDP per } \\
\text { capita }\end{array}$ & Dollars & $\begin{array}{l}\text { Zhao Lunyun et } \\
\text { al. (2012) }\end{array}$ \\
\hline imp & Imports & $\begin{array}{l}\text { Billion } \\
\text { dollars }\end{array}$ & $\begin{array}{l}\text { The China } \\
\text { Statistical } \\
\text { Yearbook }\end{array}$ \\
\hline ind & $\begin{array}{l}\text { Exports } \\
\text { exp } \\
\text { Industry } \\
\text { sector } \\
\text { value } \\
\text { added }\end{array}$ & $\begin{array}{l}\text { Billion } \\
\text { dollars }\end{array}$ & $\begin{array}{l}\text { The Statistical } \\
\text { Yearbook }\end{array}$ \\
\hline fdi & $\begin{array}{l}\text { Foreign } \\
\text { direct } \\
\text { investmen } \\
\text { t net } \\
\text { inflows }\end{array}$ & $\begin{array}{l}\text { The Ching } \\
\text { Statistical } \\
\text { Yearbook }\end{array}$ \\
\hline
\end{tabular}

\subsection{Method}

We start our empirical investigation using a panel model. It is commonly recognized that panel data sets possess several advantages over cross-sectional or time series data sets. It gives the researchers a larger number of data points. Moreover panel data models are able to capture the individual heterogeneity (at the province level in this case) by introducing an individual specific effect term in the regression model, thus improving the estimation performance (Baltagi, 2008).

We prefer linear model to log-linear model in this study mainly because of its computational simplicity, the immediate interpretability of some of its coefficients and its temporal aggregability (Galeotti and Lanza, 2005). A linear model yields constant marginal effects and variable elasticities.

\section{Estimation Results}

We estimate both two-way fixed effects and random effects models. We do choose the FE against the RE as our preferred model since the Hausman test suggests that the FE estimator remains consistent whereas the RE estimator does not and $u_{i}$ is correlated with at least one of the explanatory variables. Moreover, we decide to use the FE model with robust cluster (by province) standard errors, since that the default FE estimation overestimates the significance of every explanatory variable. The results are given in Table 2 below.
Table2. Regressions Results

\begin{tabular}{|c|c|c|}
\hline \multirow{2}{*}{ Variables } & \multicolumn{2}{|c|}{ FE (clustered robust) } \\
\hline & Coefficients & P-value \\
\hline 11 gdp & $\begin{array}{l}0.0040422 \\
(0.0009692)\end{array}$ & $0.000 * * *$ \\
\hline 11gdp_2 & $\begin{array}{l}-5.08 \mathrm{e}-07 \\
(1.14 \mathrm{e}-07)\end{array}$ & $0.000 * * *$ \\
\hline 11gdp_3 & $\begin{array}{l}2.26 \mathrm{e}-11 \\
(5.26 \mathrm{e}-12)\end{array}$ & $0.000^{* * *}$ \\
\hline $11 \mathrm{imp}$ & $\begin{array}{l}-0.0001237 \\
(0.000339) \\
\end{array}$ & 0.718 \\
\hline 11 exp & $\begin{array}{l}0.0001281 \\
(0.0002731)\end{array}$ & 0.642 \\
\hline 11ind & $\begin{array}{l}-0.0595993 \\
0.0274292 \\
\end{array}$ & $0.038 * *$ \\
\hline $11 \mathrm{fdi}$ & $\begin{array}{l}0.0003419 \\
(0.0002146)\end{array}$ & 0.122 \\
\hline $\begin{array}{l}\text { y3 } \\
\text { (year2002) }\end{array}$ & $\begin{array}{r}-0.0767381 \\
(0.06685)\end{array}$ & 0.260 \\
\hline $\begin{array}{l}\text { y4 } \\
\text { (year 2003) }\end{array}$ & $\begin{array}{c}-0.1605966 \\
(0.1365043) \\
\end{array}$ & 0.249 \\
\hline $\begin{array}{l}\text { y5 } \\
\text { (year 2004) }\end{array}$ & $\begin{array}{r}-0.4498776 \\
(0.2545077)\end{array}$ & $0.088^{*}$ \\
\hline $\begin{array}{l}\text { y6 } \\
\text { (year 2005) }\end{array}$ & \multicolumn{2}{|l|}{ Omitted } \\
\hline $\begin{array}{l}\text { y7 } \\
\text { (year 2006) }\end{array}$ & $\begin{array}{l}-1.268665 \\
(0.5627091) \\
\end{array}$ & $0.032 * *$ \\
\hline $\begin{array}{l}\text { y8 } \\
\text { (year 2007) }\end{array}$ & $\begin{array}{l}-1.701195 \\
(0.7272009)\end{array}$ & $0.026 * *$ \\
\hline $\begin{array}{l}\text { y9 } \\
\text { (year2008) }\end{array}$ & $\begin{array}{l}-2.344225 \\
(0.9035978)\end{array}$ & $0.015^{* *}$ \\
\hline
\end{tabular}

Standard errors are in parenthesis

*** $\mathrm{P}<0.01, * * \mathrm{P}<0.05, * \mathrm{P}<0.10$

According to results of the FE model with cluster robust standard error in Table 2, the variables one-year lag of GDP per capita as well as GDP $^{2}$ and GDP $^{3}$ (11gdp, 11gdp_2 and 11gdp_3) are highly significant. This implies that carbon dioxide emissions and income have a $\mathrm{N}$-shaped relationship, which is almost the same as linear relationship. The percentage of industrial value added (11ind) is significant, a rise of 1 percentage point leads to 0.06 tonnes $\mathrm{CO}_{2}$ per capita decrease, however this is the opposite from our expectation. Thus there is evidence that industry sectors have positive impact on the environment. This may be misleading because of the problem of the model specification. Since 2004, the time dummy variables are significant, and have negative signs. This may be because of steep increase of oil price since 2004, leading to provinces switching to less energy consuming and less polluting activities, thus carbon emissions reduction occurred. However the trade variables are insignificant.

This is an interesting result and may imply that there are other relationships in these models that are not being explained, but also determining the amount of the carbon emissions. 


\section{Conclusions}

This study estimates the environmental Kuznets curve for 30 provinces in China, and tries to examine the key determinants of carbon emissions. Due to the fact that other factors such as trade, industry sector value added may also have impact on $\mathrm{CO}_{2}$ emissions, we expand our estimation models by including these factors into the models as control variables. For the econometric technique, we test fixed effects and random effects of panel analysis, and we choose linear model other than log-linear models.

In general, the result shows that there is not sufficient evidence for the existence of the environmental Kuznets curve. The $\mathrm{N}$-shaped relationship between $\mathrm{CO}_{2} / \mathrm{GDP}$ relation suggests that $\mathrm{CO} 2$ emissions would firstly decrease but increase again with income growth. Industry sector value added is significant, the negative sign implies the industry sector has a positive impact on the environment, which might be misleading.

Therefore, the policy based on a "wait and grow" assumption is not adequate. Governments need to undertake policies as soon as possible to reduce levels of $\mathrm{CO}_{2}$ emissions. For individual provinces, options for economic growth with a less increase in pollution include: (i) increasing the service industry share; (ii) importing pollution intensive goods; (iii) strengthen controls on air pollutions; and (iv) increasing technology innovations on energy efficiency. However, the first two solutions reduce carbon emissions domestically on the expense of other areas' environment. Only the last one is the real solution for controlling $\mathrm{CO}_{2}$ emissions countrywide. Future policies for climate change and pollution should explicitly focus on technological innovations.

\section{Acknowledgment}

This paper is funded by the planning project of Beijing Foreign Studies University (2011XG003).

\section{References}

[1] Arrow, Bolin, Costanza, Dasgupta, Folke, Holling, Jansson, Levin, Maler, Perrings, Pimentel (1995). Economic Growth, Carrying Capacity, and the Environment. Ecological Economics. 15, 91-95.

[2] Baltagi (2008) Econometric analysis of panel data, 4th Edition, Hoboken, NJ: John Wiley \& Sons, Inc.

[3] Cole, Elliott, Fredriksson (2006). Endogenous Pollution Havens: Does FDI influence Environmental Regulations? The Scandinavian Journal of Economics. 108 (1), 157-178.

[4] Galeotti, Lanza (2005). Desperately seeking environmental Kuznets. Environmental Modelling \& Software. 20, 1379-1388.

[5] Galeotti, Lanza, Pauli (2006). Reassessing the environmental Kuznets curve for $\mathrm{CO}_{2}$ emissions: A robustness exercise. Ecological Economics. 57, 152163.

[6] Grossman, Krueger (1993). Environmental impacts of a North American Free Trade Agreement. The US Mexico Free Trade Agreement, MIT Press, Cambridge, MA, 57-125.

[7] He, Richard (2010). Environmental Kuznets curve for $\mathrm{CO}_{2}$ in Canada. Ecological Economics. 69, 1083-1093.

[8] Huang, Zhao, Li (2012). The Calculation and Influence Factor Analysis of Carbon Emissions in China. Shandong Industrial and Commercial College.

[9] Hübler, Keller (2010). Energy savings via FDI? Empirical evidence from developing countries. Environment and Development Economics. 15 (1), 5980

[10] Iwata, Okada, Samreth (2010). Empirical study on the environmental Kuznets curve for $\mathrm{CO}_{2}$ in France: The role of nuclear energy. Energy Policy. 38 (8), 40574063.

[11] Iwata, Okada, Samreth (2012). Empirical study on the determinants of $\mathrm{CO}_{2}$ emissions: evidence from OECD countries. Applied Economics. 44 (27), 3513-3519.

[12] Panayotou (1997). Demystifying the environmental Kuznets curve: Turning a black box into a policy tool. Environment and Development Economics. 2, 465484.

[13] Panayotou (2003). Economic Growth and the Environment. Economic Survey of Europe. 2, 45-72. 